\title{
Justification of the Relationship of Production Capacity and the Parameters of the Blocks at Surface Mining of Existing Kuzbass Quarry Fields
}

\author{
Alexei Selyukov ${ }^{1, *}$, Andrey Gerasimov ${ }^{2}$, and Kirill Byrdin ${ }^{2}$ \\ ${ }^{1}$ T.F. Gorbachev Kuzbass State Technical University, Department of open pit mining, 650000 Kemerovo, \\ 28 Vesennya st., Russian Federation \\ ${ }^{2}$ JSC "NC VostNII", 650002, 3 Institutskaya Str., Kemerovo, Russia
}

\begin{abstract}
Today, up to two-thirds of the world's minerals are mined in an open, more economical way. However, at the same time, billions of tons of overburden are extracted, which are piled in the dumps, where they are polluted, lose their value and, in addition, reduce the quality of the environment. The possibility of industrial use of various rocks of from quarry field characterizes the complexity of minerals extracted by surface mining. Currently, there are no clear criteria for determining the size of blocks when designing enterprises for open pit mining. In most cases, when designing open pit mines, a quarry field is conventionally divided into several blocks, which does not always ensure the optimal production capacity of the mining enterprise due to the uneven distribution of reserves in the block contours. Because of that, during the transition from one block to another, a decrease in the production capacity of the enterprise can be noted. To avoid productivity decreasing, the precise analysis of the block parameters must be performed.
\end{abstract}

\section{Introduction}

The design of a particular coal mining enterprise is based on the development strategy of the industry, which contains a long-term development plan for each basin and field for the next 1520 years. It considers the following provisions: the technical capabilities of the coal basin and a specific deposit; the priority of the development of deposits and the construction of enterprises; volumes and rates of development of production to meet the future demand for coal; power supply, water supply and sewage; housing, cultural and residential construction; repair bases and other objects of regional significance; the number of workers; investments and coal prices, profitability and labor productivity. The design of the enterprise includes two stages: drawing a technical and economic project for construction or reconstruction of the enterprise; development of starting technical project of the enterprise, combined with the working drawings.

\footnotetext{
* Corresponding author: sav.ormpi@,kuzstu.ru
} 


\section{Materials and Methods}

Open pit coal mining technologies in Kuzbass should be based on an acceptable combination of production needs and ecology [1-3]. These solutions include green technologies [4-6]. For the first time a block method for developing quarry fields was proposed in 1972 by B.T. Rutkovsky [6], the essence of which is the preliminary division of the quarry field into independent blocks developed sequentially with the placement of internal dumps in the previous block.

After analyzing the design documentation, in terms of determining the dimensions of the blocks, it was found that in the design of open pits, the quarry field is conventionally divided in two blocks, and their parameters are often not supported by specific criteria. In general, it has been established that the initial unit should accommodate some portion of the rocks, but the criteria for choosing the capacity of overburden volumes placed in the internal dump are also presented in the project without the most influencing factors. When working out the second block in turn, an internal dump is formed in the previous block [7-17]. Initial methodological approaches to the study of this issue are given in [14].

\section{Results and Discussion}

Based on previous studies and the direction of the task being studied, we will analyze the quarry field of the Kuznetsk Coal Basin (Kuzbass), which is territorially related to the Prokopevsk-Kiselevsky geological and economic region. The considered section of open pit mining is worked out using a dimple longitudinal two-sided mining nethod [8] with a block order of mining (Fig. 1).

The quarry field of this section (Fig. 1) is processed by two blocks. The Northern block was initially put into operation and worked out with greater intensity, after which the Southern block is introduced. After the completion of the development of the Northern block, an internal dump is placed in its developed space.

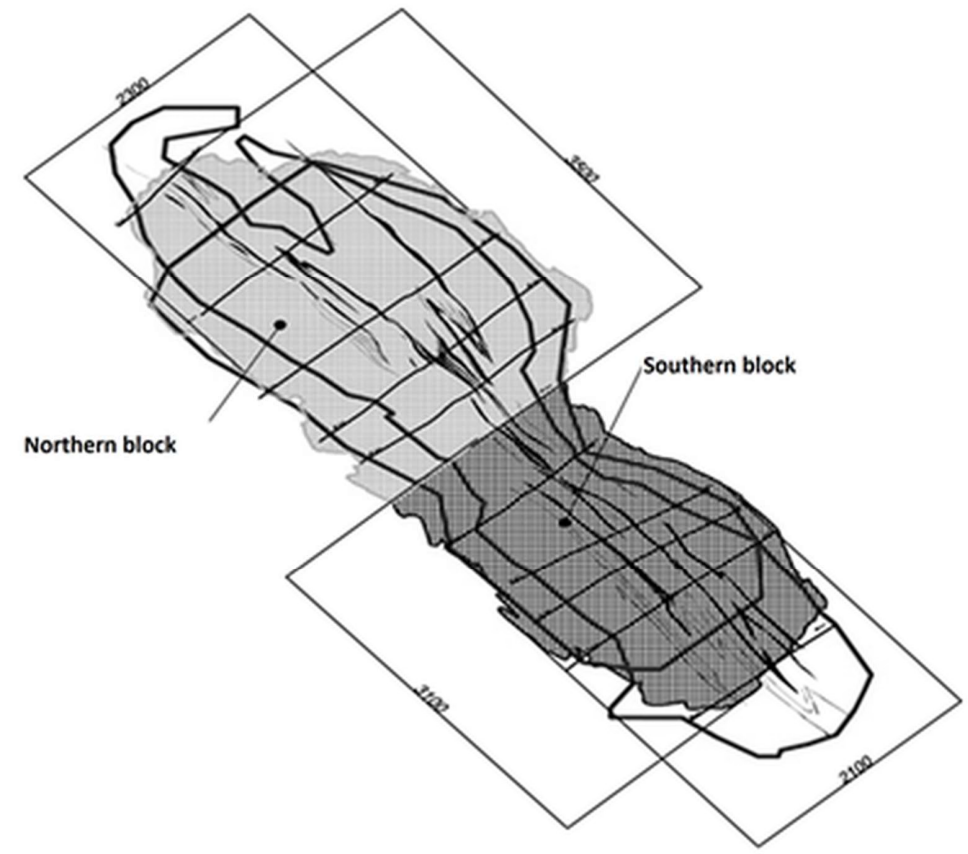

Fig.1. The sizes of the blocks under the project. 
Initially, the Northern and Southern blocks had dimensions of $3.5 \mathrm{~km} \times 2.3 \mathrm{~km}$ and $3.1 \mathrm{~km}$ $\times 2.1 \mathrm{~km}$, respectively. Knowing the size of the blocks, we can conclude that the quarry field is conditionally divided in half. Analyzing the volumes, the production capacity of the site is calculated according to the rate of deeping of mining operations according to (1) in accordance with the instruction on the calculation of production capacity.

$$
N_{c a p}^{d}=\frac{Q_{a} \times T_{a}}{H_{w z}}
$$

where: $\mathrm{N}_{c a p}^{\mathrm{d}}$ - section's capacity accordingly the deeping rate, thouthand tons per year;

$Q_{a}$ - industrial coal reserves volume, thousand tons;

$T_{a}$ - annual deeping year, $\mathrm{m} /$ year (accordingly the project);

$H_{W z}$ - working zone width, $\mathrm{m}$.

$$
N_{\text {cap }}^{d}=\frac{92852041 \times 5.6}{256}=2031 \text { thousand tons per year }
$$

Table 1. Estimated design capacity of the block at the rate of deeping.

\begin{tabular}{|c|c|c|c|c|c|c|}
\hline $\begin{array}{c}\text { Block } \\
\text { name }\end{array}$ & $\begin{array}{c}\text { Rock mass, } \\
\mathbf{m}^{\mathbf{3}}\end{array}$ & $\begin{array}{c}\text { Overburden, } \\
\mathbf{m}^{\mathbf{3}}\end{array}$ & Coal, tons & $\begin{array}{c}\text { Work. } \\
\text { zone } \\
\text { height, } \\
\mathbf{m}\end{array}$ & $\begin{array}{c}\text { Annual } \\
\text { deeping } \\
\mathbf{m} / \mathbf{y e a r}\end{array}$ & $\begin{array}{c}\text { Capacity } \\
\text { accordingly } \\
\text { the deeping } \\
\text { rate, thous. } \\
\text { tons/year }\end{array}$ \\
\hline $\begin{array}{c}\text { Southern } \\
\text { block }\end{array}$ & 1043833029.4 & 975053739.6 & 92852041 & 256 & 5.6 & 2031 \\
\hline $\begin{array}{c}\text { Northern } \\
\text { block }\end{array}$ & 1697296796.3 & 1563125151.2 & 181131721 & 224 & 6 & 4852 \\
\hline
\end{tabular}
2).

Analyzing the table presented, a schedule of mining operations in blocks is compiled (Fig.

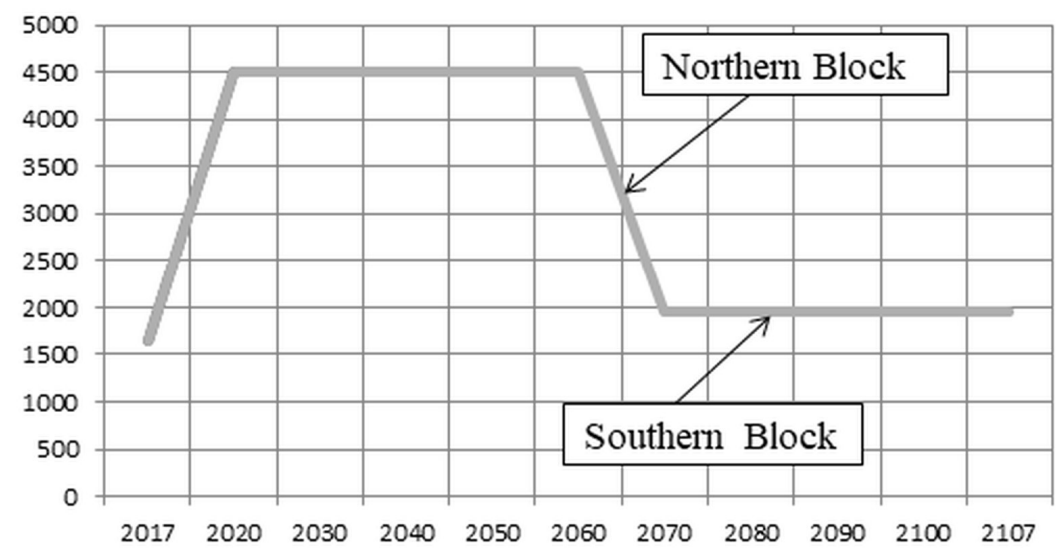

Fig.2. Production schedule for the blocks (thousand tons / year).

Based on the graph, it can be seen that the production capacity in the Northern block is much higher than in the Southern block, thus it can be confirmed that the reserves within the blocks are unevenly distributed. Due to that fact, during the development of the blocks in the North-South sequence, there will be a drop in production capacity what should not happen. 
By changing the size of blocks within the license it is possible to obtain a redistribution of reserves in the contours of the blocks with the same sequence of mining (Fig. 3).

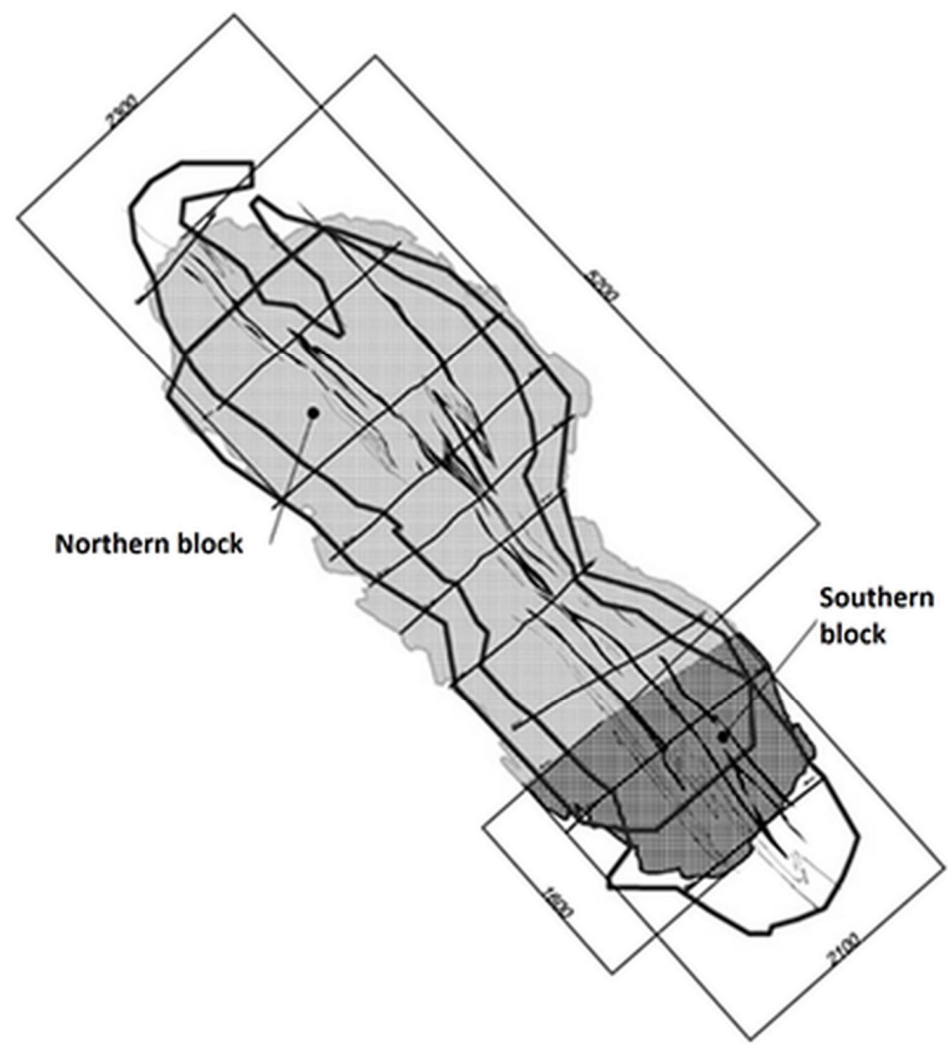

Fig.3. The sizes of the blocks after the first adjustment.

For convenience of further calculation, we changed the size of the blocks on 2 exploration lines. By reducing the Southern block, respectively increasing the Northern one, we get new block sizes that will be: $1.6 \mathrm{~km} \times 2.1 \mathrm{~km}$ for South; $5.2 \mathrm{~km} \times 2.3 \mathrm{~km}$ for North. Given the size of the blocks, we distributed the volumes of rock mass, overburden and coal along exploration lines.

Analyzing the obtained volumes we made the calculation of the production capacity of the segment at the rate of deeping according to (1). The estimated design capacity of the segment at the rate of deeping is given in Tab. 2

Table 2. Estimated design capacity of the site at the rate of deeping.

\begin{tabular}{|c|c|c|c|c|c|c|}
\hline $\begin{array}{c}\text { Block } \\
\text { name }\end{array}$ & $\begin{array}{c}\text { Rock mass, } \\
\mathbf{m}^{\mathbf{3}}\end{array}$ & $\begin{array}{c}\text { Overburden, } \\
\mathbf{m}^{\mathbf{3}}\end{array}$ & Coal, tons & $\begin{array}{c}\text { Working } \\
\text { zone } \\
\text { height, } \\
\mathbf{m}\end{array}$ & $\begin{array}{c}\text { Annual } \\
\text { deeping, } \\
\text { m/year }\end{array}$ & $\begin{array}{c}\text { Capacity } \\
\text { accordingly } \\
\text { the deeping } \\
\text { rate, thous. } \\
\text { tons/year }\end{array}$ \\
\hline $\begin{array}{c}\text { Southern } \\
\text { block }\end{array}$ & 472049348.5 & 431050243.6 & 55348791.6 & 256 & 5.6 & 1211 \\
\hline $\begin{array}{c}\text { Northern } \\
\text { block }\end{array}$ & 2269080477 & 2107128647 & 218634970.5 & 224 & 6 & 5856 \\
\hline
\end{tabular}
$3)$.

Analyzing the presented table, a schedule of mining operations in blocks is compiled (Fig. 


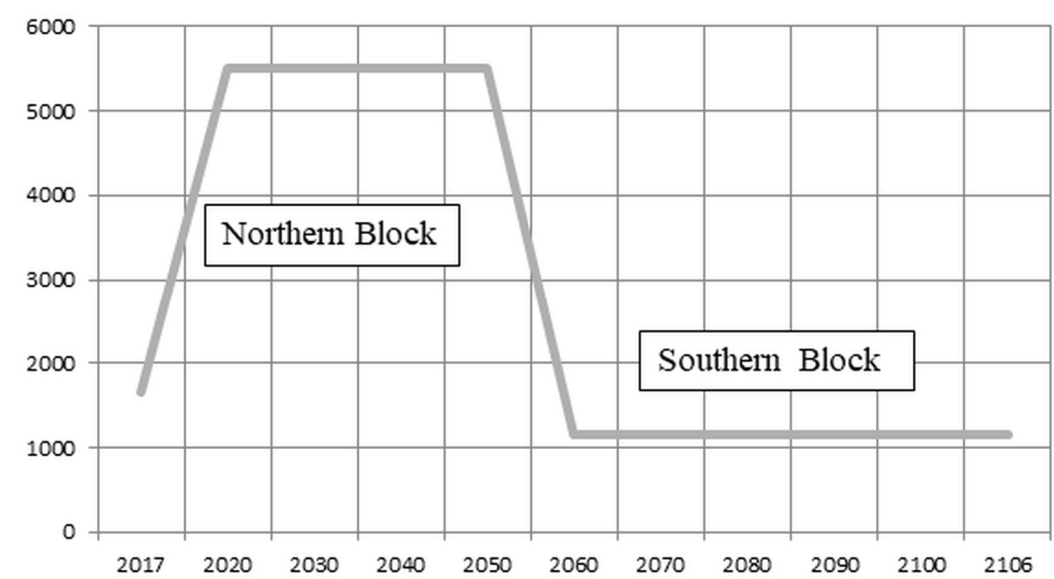

Fig.3. The schedule of mining operations in blocks (thousand tons / year).

Based on the graph, it can be seen that the production capacity in the Northern block is also higher than in the Southern block as in the first case, thereby it can be confirmed that the reserves within the blocks are unevenly distributed, which will result in the development of blocks in the North-South sequence there is a drop in production capacity.

By changing the size of blocks within a license, it is possible to obtain a redistribution of reserves in the contours of blocks with the same sequence of mining (Fig. 4).

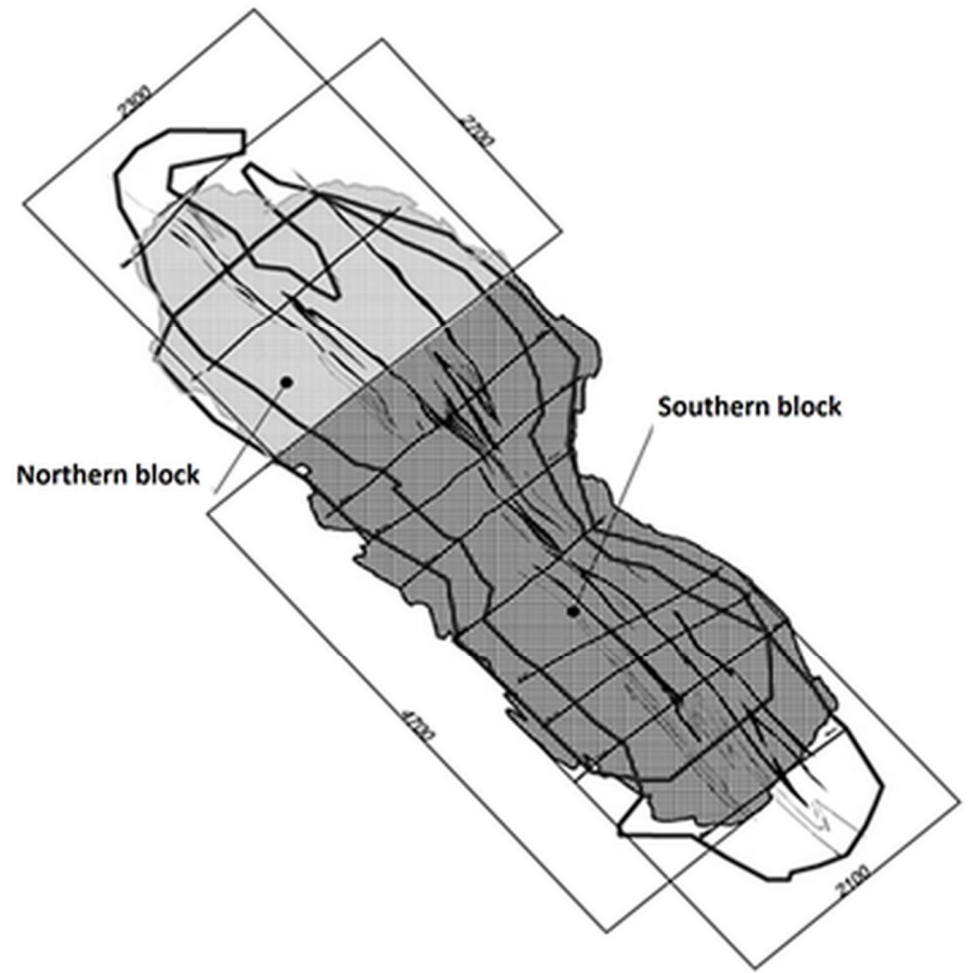

Fig.4. The sizes of the blocks after the second adjustment. 
The block sizes were changed on 2 exploration lines. Decreasing the Northern block, respectively, increasing the Southern one, we obtain new blocks that will be: $4.7 \mathrm{~km} \times 2.1 \mathrm{~km}$ for Southern; $2.7 \mathrm{~km} \times 2.3 \mathrm{~km}$ for Northern. Given the size of the blocks, we distributed the volumes of rock mass, overburden and coal along exploration lines.

Analyzing the obtained volumes we made the calculation of the production capacity of the segment at the rate of deeping of mining operations according to the (1). The estimated design capacity of the site at the rate of deeping is given in Tab. 3

Table 3. Estimated design capacity of the site at the rate of deeping.

\begin{tabular}{|c|c|c|c|c|c|c|}
\hline $\begin{array}{c}\text { Block } \\
\text { name }\end{array}$ & $\begin{array}{c}\text { Rock mass, } \\
\mathbf{m}^{\mathbf{3}}\end{array}$ & $\begin{array}{c}\text { Overburden, } \\
\mathbf{m}^{\mathbf{3}}\end{array}$ & Coal, tons & $\begin{array}{c}\text { Working } \\
\text { zone } \\
\text { height, } \\
\mathbf{m}\end{array}$ & $\begin{array}{c}\text { Annual } \\
\text { deeping, } \\
\text { m/year }\end{array}$ & $\begin{array}{c}\text { Capacity } \\
\text { accordingly } \\
\text { the deeping } \\
\text { rate, thous. } \\
\text { tons/year }\end{array}$ \\
\hline $\begin{array}{c}\text { Southern } \\
\text { block }\end{array}$ & 1702940903.2 & 1585920056.0 & 157978144 & 256 & 5.6 & 3456 \\
\hline $\begin{array}{c}\text { Northern } \\
\text { block }\end{array}$ & 1038188922.5 & 952258834.8 & 116005618 & 224 & 6 & 3107 \\
\hline
\end{tabular}
(Fig. 5).

Analyzing the presented table, a schedule of mining operations in blocks is compiled

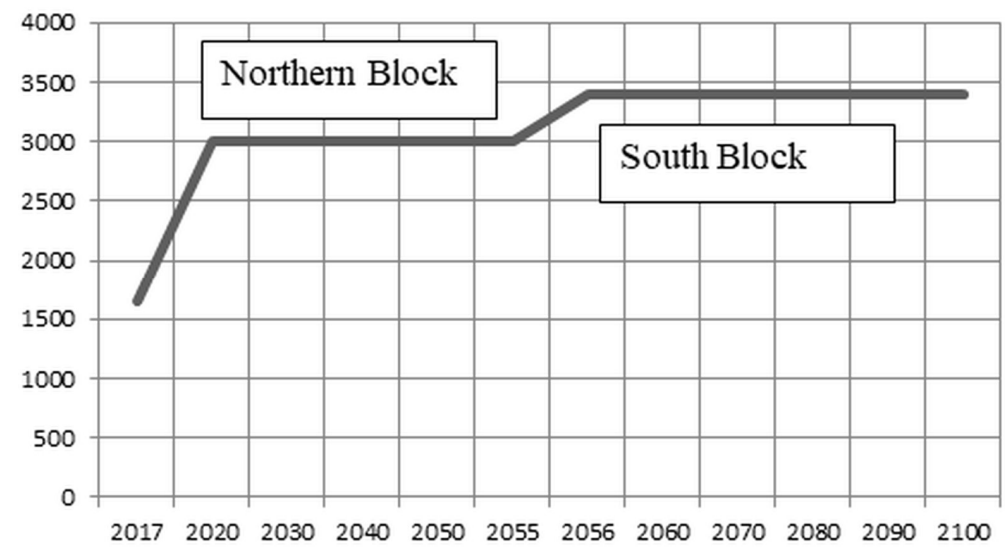

Fig.5. Schedule of mining work on the blocks.

Comparing three time schedules of mining operations (Fig. 2, 3, 5), a transition of mining from one block to another is clearly seen.

In the first and second cases, the production capacity drops, which negatively affects the technical and economic indicators of coal mining enterprise. In the third case, the production capacity of the open pit mine segment does not fall, but, on the contrary, when the second block in turn is processed, the output of the section increases, which has a positive effect on the technical and economic indicators of the enterprise.

\section{Conclusions}

Thus, by changing the volumes of the blocks within the quarry field, there is an increase in the volume of coal in one block and a decrease in coal in another.

As a result, you can adjust the production capacity of the segment in the direction of increasing productivity during the transition from one unit to another. Consequently, the size of 
blocks and the volume of reserves concentrated in the contours of these blocks directly affect the production capacity of the enterprise.

\section{References}

1. M. Tyulenev, S. Markov, M. Cehlar, S. Zhironkin, M. Gasanov, Acta Montanistica Slovaca, 23:4, 368-377 (2018)

2. O. Litvin, M. Tyulenev, S. Zhironkin, S. Prokopenko, Acta Montanistica Slovaca, 22:2, 146152 (2017)

3. M. Tyulenev, O. Litvin, M. Cehlár, S. Zhironkin, M. Gasanov, Acta Montanistica Slovaca, 22:3, 296-302 (2017)

4. M. Tyulenev, S. Markov, M. Cehlar, S. Zhironkin, M. Gasanov, Acta Montanistica Slovaca, 23:4, 368-377 (2018)

5. T. Gvozdkova, M. Tyulenev, S. Zhironkin, V. A. Trifonov, Yu. M. Osipov, IOP Conf. Ser.: Earth Environ. Sci., 50:1, 012010 (2017)

6. M. Cehlár, J. Janočko, Z. Šimková, T. Pavlik, M. Tyulenev, S. Zhironkin, M. Gasanov, Resources, 8:1, 21 (2019)

7. B.T. Rutkovsky, Block method of mining quarry with a large strike (KuzPI, Kemerovo, 1972)

8. A. I. Koryakin, A.V. Selyukov, Bulletin of KuzSTU, 2, 66-68 (2010)

9. A.V. Selyukov, Natural and Technical Sciences, 3:81, 94-97, (2015)

10. A.V. Selyukov, Mountain Journal, 5, 11-16 (2016)

11. A.V. Selyukov, Zapiski Mining Institute, 219, 387-391 (2016)

12. V.N. Makarov, A.I. Koryakin, Technology of opencast mining in the fields of liquidated mines (KuzSTU, Kemerovo, 2010)

13. A.V. Gerasimov, A.A. Zhmakina, K.A. Byrdin, Determining the sequence of development of open pit coal mines when they are divided into blocks (KuzSTU, Kemerovo, 2015)

14. V.V. Rzhevsky, Technology and integrated mechanization of open pit mining (Nedra, Moscow, 1975) 